\title{
Institutional Determinants Of Reducing Energy Efficiency Gaps In The Economy
}

https://doi.org/10.21272/sec.4(1).122-128.2020

Vladyslav Pavlyk, ORCID iD: https://orcid.org/0000-0003-1222-8937

Postgraduate Student, Marketing Department, Sumy State University, Ukraine

\begin{abstract}
The article examines approaches to the analysis of factors that influence the difference between capacity and current energy production in the country, that is, the gap in energy efficiency in the economy. To investigate the main trends in the theory of energy efficiency and energy conservation, a bibliometric analysis was carried out (using VOSViewer v.1.6.10 toolkit), the object of which was 1428 scientific articles in publications indexed by the Scopus scientometric database. The analysis showed that in 2019, scientists published 1.5 times more work on the subject than in 2005, and revealed five clusters of scientists who investigated the problems of the connection between institutional determinants and lack of electricity in the country. The research hypothesis is to test the impact of institutional determinants on the energy efficiency gap in the economy. For the assessment of institutional determinants, such indicators of public administration effectiveness as: "rule of law", "government efficiency", "political stability and the absence of violence / terrorism", "quality of regulatory activity" and "anti-corruption" have been used. The source of statistical information is the Worldwide Governance Indicator Global Eurojustice Reports and Eurostat data, the Pedroni co-integration test and the least-squares method, the calculations were made using EViews 11. Objects of study are EU and Ukraine, period for analysis - 2009-2018. The findings confirmed the statistically significant impact of institutional determinants on the energy efficiency gap in the economy: increasing government efficiency and political stability by 1 mind. units leads to a reduction in the energy efficiency gap of 0.47 and $0.54 \mathrm{dm}$. units in accordance. It has been empirically proven that improving the quality of regulatory activity and improving the rule of law in Ukraine is one mind. units causes energy efficiency gains of 0.34 and 0.41 $\mathrm{dm}$. units in accordance. The results of the study can be used by state and local authorities to improve the country's energy efficiency and energy efficiency systems.
\end{abstract}

Keywords: energy balance, renewable energy sources, energy gap, corruption, quality of public administration, political stability, government efficiency, energy efficiency, energy conservation, institutional determinants.

JEL Classification: O13, P18, P28, P48, Q42, Q43.

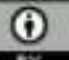

This work is licensed under a Creative Commons Attribution 4.0 International License.

Cite as: Pavlyk, V. (2020). Institutional Determinants Of Assessing Energy Efficiency Gaps In The National Economy. SocioEconomic Challenges, 4(1), 122-128. https://doi.org/10.21272/sec.4(1).122-128.2020.

(C) The Author, 2020. This article is published with open access at Sumy State University.

\section{Introduction}

The ongoing trends of economic development provoke the overconsumption of energy recourses. Such tendency lead to decreasing of the country's energy balance and security. From the other side, the high level of competitiveness at the world market contribute the relevant reactions from the governments to implement capable instruments to increase the country's competitiveness. Besides, the refocusing of the world community on green development justify the increase of the country's energy efficiency by the extending of green innovations and technologies. 


\section{Literature review}

The analyses of 1428 documents which indexed in Scopus showed that pics of the papers on linking between energy efficiency and institutional parameters were in 2011 and 2015 years. Besides, the numbers of the documents began to increase in 1998, then in 2006.

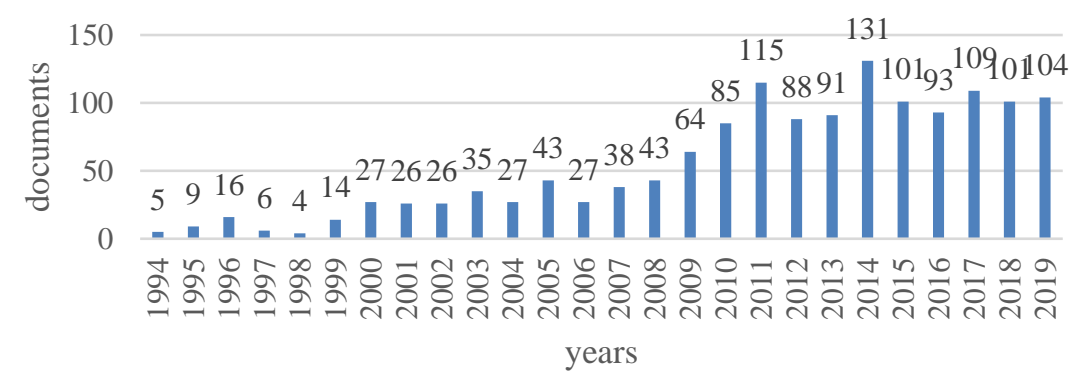

Figure 1. The dynamic of the scientific paper on energy efficiency and institutional parameters in
Scopus during 1994-2019

Sources: compiled by the author using Scopus Tools Analysis.

Considering the finding in Figure 1, after 2014, the numbers of the document had decreased. At the same time, in 2019, the number of published papers increased in 1,5 times compare with the 2005 year. Omer A. M. wrote the most cited paper (720 citations in Scopus) in the high ranked journal - "Renewable and Sustainable Energy Reviews". In the article (Omer, 2008) the scientist proved the statistical significance was linking between energy efficiency, renewable energy and sustainable development. The scientists in the paper (Newell et al., 1999) confirmed the positive impact of government regulation and innovations on the country's energy efficiency. The Turkish authors in the paper (Şengül et al., 2015) checked the hypothesis on linking between government supporting of renewable energy, energy efficiency and $\mathrm{CO} 2$ emissions using the multi-criteria decision methods - TOPSIS. The scientists in the papers (Lyulyov et al., 2018) proved that energy efficiency had a statistically significant impact on macroeconomic stability. Chygryn O. Yu. and Krasniak V. S. (2015) concluded that green investment had positive impact on extending of green energy projects which allow increasing of country's energy efficiency. Besides, the numerous scientists (Yevdokimov et al., 2018; Chygryn et al., 2018; Pimonenko et al., 2018) proved that renewable energy effected on the country's energy balance. The Chinese scientists Wang Q. and Yuan Q. (2020) and Turkish scientists (Konur et al., 2019) tried to allocate the main technical and economic parameters which allow decreasing the energy efficiency gap. The results of analyses showed that some cluster of the scientists in the papers (Broberg et al., 2019; Dunlop, 2019; Alberini, 2019; Kwilinski, 2018) analysed the energy efficiency gap at the company level and proved the green innovation allowed decreasing the volume of the energy efficiency gap. The massive range of the scientific directions established by the findings from the bibliometric analysis using VOSviewer (Figure 2, see below).

The findings allow identifying five clusters of scientific directions. Each cluster contained 23 items. The first scientific clusters connected with energy efficiency. This cluster had more than ten links with other clusters. The second cluster connected with energy policy and had links with the cluster of renewable energy. The third cluster could be called as government policy. The fourth cluster located close to energy policy and energy efficiency - sustainable development. The last fifth cluster involved papers which analysed economic growth and energy efficiency. Despite the numerous investigations, not a lot of scientists had analysed the linking between institutional parameters and energy efficiency of the country. In this case, the aim of the paper was checking the hypothesis as follows:

H1: the impact of the institutional determinants on the country's energy efficiency gap.

\section{Methodology and research methods}

The hypothesis of the investigation was checking the impact of the institutional determinants on the energy efficiency gap in the national economy. Under the study, the authors used the World Governance Indicators for assessment of the institutional determinants as follows: the rule of law, government efficiency voice and accountability, political stability, regulatory quality and control of corruption. The energy efficiency gap 
proposed to estimate by the indicators of energy efficiency calculated by the Eurostat. For the analysis, the raw dates were selected from the database as follows: World Governance Indicators, World Data Bank, Eurostat. The explanation of the variables and sources of raw data showed in Table 1.

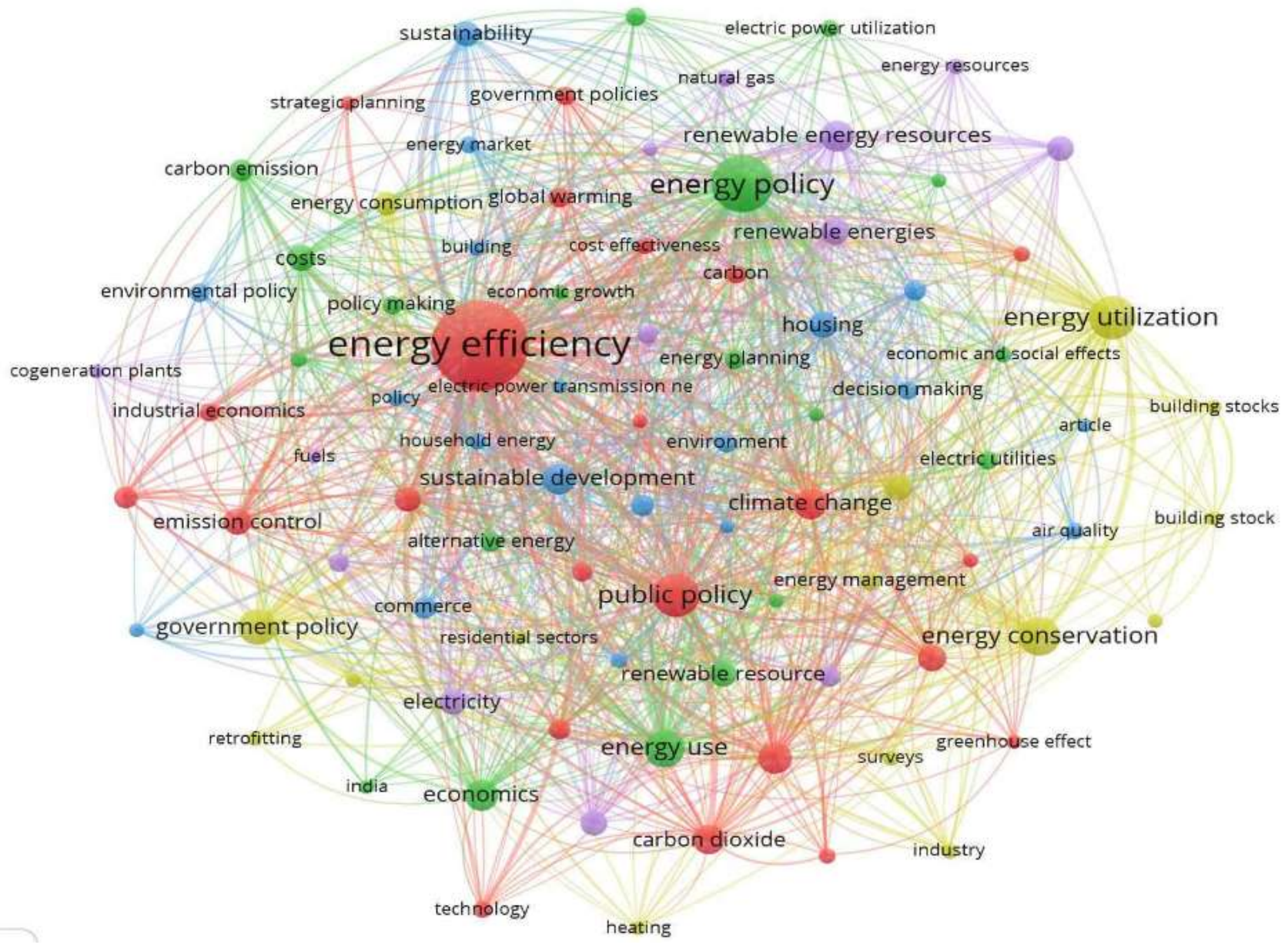

Figure 2. Bibliometric analysis of the scientific paper on energy efficiency and government policy in Scopus

Sources: compiled by the author using VOSviewer.

Table 1. Explanation of the selected indicators

\begin{tabular}{|c|c|c|}
\hline VARIABLES & SYMBOLS & SOURCES \\
\hline The rule of law & RUL & \multirow{6}{*}{$\begin{array}{l}\text { Worldwide Governance Indicators } \\
\text { (WGI) project reports (Kaufmann et al., } \\
\text { 2010-2019) }\end{array}$} \\
\hline Government efficiency & GEF & \\
\hline Voice and accountability & VA & \\
\hline Political stability & PS & \\
\hline Regulatory quality & REQ & \\
\hline Control of corruption & $\mathrm{CC}$ & \\
\hline Energy efficiency & $\mathrm{EE}$ & Eurostat, 2019 \\
\hline
\end{tabular}

Sources: compiled by the author.

All calculation was done using the software EViews 11. The object of investigation was: EU countries and Ukraine, time 2007-2019. The study used a panel cointegration test which allowed defining the cointegration between selected parameters.

\section{Results}

At the first stage, the descriptive statistic of all variables was done by using EViews 11 . The finding showed in Table 2. 
Table 2. Descriptive statistics the selected indicators

\begin{tabular}{|c|c|c|c|c|c|}
\hline SYMBOLS & Mean & Median & Maximum & Minimum & Std. Dev \\
\hline EE & 52,34 & 23,13 & 315,15 & 0,71 & 72,06 \\
\hline GEF & 1,06 & 1,07 & 2,24 & $-0,83$ & 0,65 \\
\hline PS & 0,66 & 0,75 & 1,46 & $-2,02$ & 0,54 \\
\hline REQ & 1,08 & 1,1 & 2,04 & $-0,63$ & 0,58 \\
\hline RUL & 1,04 & 1,07 & 2,1 & $-0,82$ & 0.73 \\
\hline VA & 1,00 & 1,06 & 1,74 & $-0,32$ & 0,48 \\
\hline CC & 0,93 & 0,88 & 2,45 & $-1,13$ & 0,89 \\
\hline
\end{tabular}

Sources: compiled by the author.

The raw data were not stationary, considering the findings in Table 1. In this case, the next stage is the normalisation of the data. After the normalisation all date become stationary. The correlation matrix in graph option showed in Figure 3.

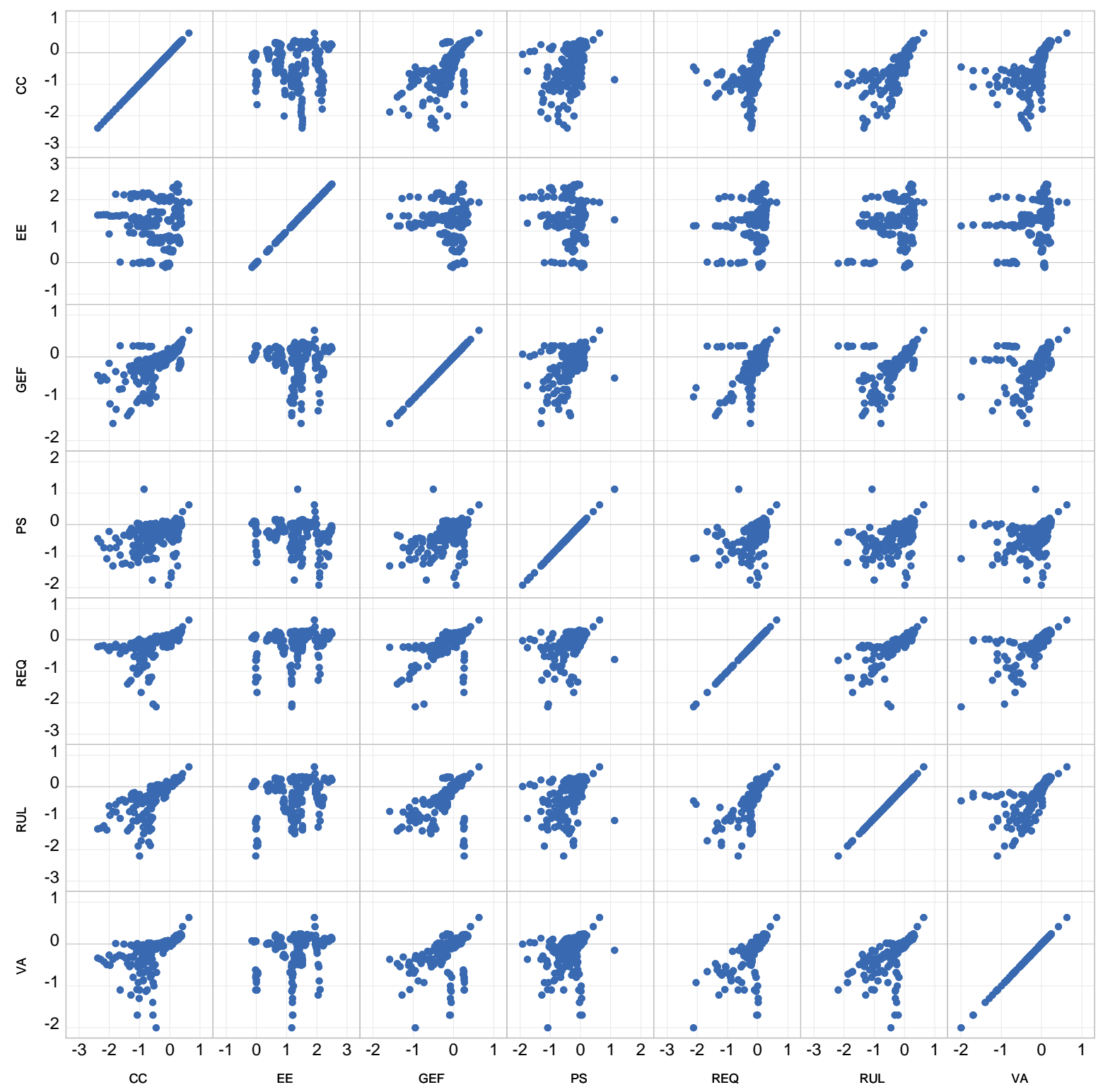

Figure 3. Graph of the correlation matrix of the rule of law, government efficiency voice and accountability, political stability, regulatory quality and control of corruption, energy efficiency 
The Pedroni cointegration tests were done, after the normalisation. It was allowed checking hypothesis on cointegration between variables. Besides, for that purpose the author used the least square model. The findings of the cointegration presented in Table 2 .

Considering the empirical results in Table 2, six from eleven results of the Pedroni test eliminate the null hypothesis - no cointegration of the panel data. The cointegration existed on significance level - $1 \%$ and $5 \%$. Thus, it allowed concluding that the multicounty panel data are cointegrated. In this case, the between selected variables the long-term relationship existed. It means that all determinants (the rule of law, government efficiency voice and accountability, political stability, regulatory quality and control of corruption, energy efficiency) were cointegrated and statistical significance at the level $1 \%$ and $5 \%$. At the next stage of the study, the impact of institutional parameters on energy efficiency was checked. For that purpose, we used the panel least square method.

Table 3. Pedroni cointegration test between selected variables

\begin{tabular}{|c|c|c|c|}
\hline Dimension & Test Statistics & Statistics & Probability \\
\hline \multirow{4}{*}{ Within-dimension } & panel v-statistic & $-2,73$ & 0,99 \\
\cline { 2 - 4 } & panel rho-statistic & 6,54 & 1,00 \\
\cline { 2 - 4 } & panel PP-statistic & $-8,79$ & 0,00 \\
\cline { 2 - 4 } & panel ADF-statistic & $-9,24$ & 0,00 \\
\cline { 2 - 4 } & \multicolumn{3}{|c|}{ (weighted statistic) } \\
\cline { 2 - 4 } & panel v-statistic & $-2,77$ & 0,99 \\
\cline { 2 - 4 } & panel rho-statistic & 6,41 & 1,00 \\
\cline { 2 - 4 } & panel PP-statistic & $-10,31$ & 0,00 \\
\cline { 2 - 4 } & panel ADF-statistic & $-7,52$ & 0,00 \\
\hline \multirow{3}{*}{ Between-dimension } & group rho-statistic & 8,85 & 1,00 \\
\cline { 2 - 4 } & group PP-statistic & $-15,02$ & 0,00 \\
\cline { 2 - 4 } & group ADF-statistic & $-9,51$ & 0,00 \\
\hline
\end{tabular}

Note: *and $* *$ represent significance at the $1 \%$ and $5 \%$ levels.

Sources: compiled by the author.

The findings showed in Table 4.

Table 4. Findings of the assessment of the institutional parameters impact on the energy efficiency of the country

\begin{tabular}{|c|c|c|c|c|}
\hline SYMBOLS & Coefficient & Standard Error & $\mathrm{t}$-Statistic & Probability \\
\hline GEF & 0,47 & 0,14 & 3,45 & 0,0006 \\
\hline PS & 0,57 & 0,1 & 5,53 & 0,0000 \\
\hline REQ & 0,34 & 0,15 & 2,204 & 0,0282 \\
\hline RUL & 0,41 & 0,14 & 2,93 & 0,0037 \\
\hline $\mathrm{VA}$ & 0,18 & 0,14 & 1,25 & 0,2121 \\
\hline $\mathrm{CC}$ & 0,04 & 0,1 & 0,36 & 0,7173 \\
\hline $\mathrm{C}$ & 1,26 & 0,04 & 32,36 & 0,0000 \\
\hline & & $\mathrm{R}^{2}$ & \multicolumn{2}{|c|}{0,56} \\
\hline & & F-statistic & \multicolumn{2}{|c|}{13,49} \\
\hline & & Prob (F-statistic) & \multicolumn{2}{|c|}{0,000} \\
\hline & & urbin-Watson stat & \multicolumn{2}{|c|}{0,008} \\
\hline
\end{tabular}

Sources: compiled by the author.

The empirical results allow concluding that voice and accountability, and corruption control did not have a statistically significant impact on the country's energy efficiency. At the same time, government efficiency and political stability had a very considerable effect on energy efficiency at $1 \%$ level. Thus, increasing by one point of government efficiency and political stability leads to swelling of energy efficiency on 0,47 and 0,54 point relevant. The parameters of regulation policy and the rule of law had a statistical significance effect at level 5\% on energy efficiency. The increasing of REQ and RUL by one point provoked the increase of energy efficiency by 0,34 and 0,41 corresponding. The coefficient of determination $\left(\mathrm{R}^{2}=0,56\right)$ demonstrated that findings of the model were adequate and variation of selected dependent variables (the rule of law, government efficiency voice and accountability, political stability, regulatory quality and control of corruption) allowed explaining $56 \%$ variation of the country's energy efficiency. 


\section{Conclusion}

The empirical data allow concluding that the interest from the scientist in investigating issues which connected with the country's energy efficiency began to increase in 1998, then the second pic was in 2006. Besides, the range of the scientific directions proved by the findings from the bibliometric analysis. The results allowed identifying the five clusters of the scientific schools as follows: The findings allow identifying five clusters of scientific directions: energy efficiency, energy policy, sustainable development, government policy, economic growth and energy efficiency. Such range of the clusters proved that not a lot of scientists analysed the impact of institutional parameters on the energy efficiency gap. The findings of Pedroni cointegration test confirmed the cointegration among selected variables. The empirical data proved the hypothesis of the statistically significant impact of the institutional parameters on the energy efficiency of the country. In this case, it allowed concluding that improving the governance efficiency and solving the issues with the political stability leads to the increase of energy efficiency and corresponding to decreasing of the energy efficiency gap of the national economy. At the same time, the activities for improving political stability should be accompanied by the relevant legislative and regulative directives, which allowed decreasing of the energy efficiency gap by 0,34 and 0,41 corresponding.

\section{References}

1. Alberini, A. (2019). Revealed versus stated preferences: What have we learned about valuation and behavior? Review of Environmental Economics and Policy, 13(2), 283-298. doi:10.1093/reep/rez010

2. Broberg, T., Egüez, A., \& Kažukauskas, A. (2019). Effects of energy performance certificates on investment: A quasi-natural experiment approach. Energy Economics, 84 doi: 10.1016/j.eneco.2019.104480

3. Chygryn, O. Yu., \& Krasniak, V. S. (2015). Theoretical and applied aspects of the development of environmental investment in Ukraine. Marketing and Management of Innovations, (3), 226-234. http://mmi.fem.sumdu.edu.ua/en/journals/2015/3/226-234

4. Chygryn, O., Pimonenko, T., Luylyov, O., \& Goncharova, A. (2018). Green Bonds like the Incentive Instrument for Cleaner Production at the Government and Corporate Levels Experience from EU to Ukraine. Journal of Advanced Research in Management, 9(7), 1443-1456. https://doi.org/10.14505//jemt.v9.7(31).09

5. Dunlop, T. (2019). Mind the gap: A social sciences review of energy efficiency. Energy Research and Social Science, 56. doi: https://doi.org/10.1016/j.erss.2019.05.026

6. Eurostat. (2019). Energy efficiency. https://ec.europa.eu/eurostat/cache/metadata/EN/nrg_ind_eff_esms.htm

7. Kaufmann Daniel, Kraay Aart and Mastruzzi Massimo (2010-2019). "The Worldwide Governance Indicators : A Summary of Methodology, Data and Analytical Issues". World Bank Policy Research Working Paper No. 5430. Available at: http://papers.ssrn.com/sol3/papers.cfm?abstract_id=1682130

8. Konur, O., Bayraktar, M., Pamik, M., Kuleyin, B., \& Nuran, M. (2019). The energy efficiency gap in turkish maritime transportation. Polish Maritime Research, 26(3), 98-106. doi: https://doi.org/10.2478/pomr-2019-0050

9. Kwilinski, A. (2018). Mechanism of modernisation of industrial sphere of industrial enterprise in accordance with requirements of the information economy. Marketing and Management of Innovations, (4), 117. http://doi.org/10.21272/mmi.2018.4-11

10. Lyulyov, O., Chygryn, O., \& Pimonenko, T. (2018). National brand as a marketing determinant of macroeconomic stability. Marketing and Management of Innovations, (3), 142-152. https://doi.org/10.21272/mmi.2018.3-12

11. Newell, R. G., Jaffe, A. B., \& Stavins, R. N. (1999). The induced innovation hypothesis and energy-saving technological change. Quarterly Journal of Economics, 114(3), 941-975. doi: https://doi.org/10.1162/003355399556188

12. Omer, A. M. (2008). Energy, environment and sustainable development. Renewable and Sustainable Energy Reviews, 12(9), 2265-2300. doi: https://doi.org/10.1016/j.rser.2007.05.001

13. Pimonenko, T., Lyulyov, O., Chygryn, O., \& Palienko, M. (2018). Environmental Performance Index: relation between social and economic welfare of the countries. Environmental Economics, 9(3), 1. Doi: $\underline{10.21511 / \mathrm{ee} .09(3) .2018 .01}$ 
14. Şengül, Ü., Eren, M., Eslamian Shiraz, S., Gezder, V., \& Sengül, A. B. (2015). Fuzzy TOPSIS method for ranking renewable energy supply systems in turkey. Renewable Energy, 75, 617-625. doi: https://doi.org/10.1016/j.renene.2014.10.045

15. Wang, Q., \& Yuan, Q. (2020). Energy-saving and emission reduction potential of the tobacco industry: A case study of China's 18 cigarette enterprises. Journal of Cleaner Production, 244 doi: 10.1016/j.jclepro.2019.118429

16. Yevdokimov, Y., Chygryn, O., Pimonenko, T., \& Lyulyov, O. (2018). Biogas as an alternative energy resource for Ukrainian companies: EU experience. Innov. Mark, 14, 7-15. https://doi.org/10.3390/en12203891 